\title{
Two Parnassius neotype designations (Lepidoptera: Papilionidae)
}

\author{
Ава обозначения неотипов в роде Parnassius \\ (Lepidoptera: Papilionidae)
}

\author{
S.K. Korb \\ C.K. Корб
}

Русское Энтомологическое Общество, П.О. 97 Нижний Новгород, RF-603009, Россия. E-mail: stanislavkorb@list.ru Russian Entomological Society, Nizhny Novgorod Branch, P.O. Box 97 Nizhny Novgorod, RF-603009, Russia.

KEY WORDS: Parnassius, neotype designations, nomenclature.

КЛЮЧЕВЫЕ СЛОВА: Parnassius, обозначения неотипов, номенклатура.

ABSTRACT. Two neotypes of Parnassius, namely the neotype of Parnassius corybas Fischer de Waldheim, 1823 from "Kamchatka, Esso environs" and the neotype of Parnassius nomion Fischer de Waldheim, 1823 from "Kiachta", are designated in the present paper. The neotype specimens as far as the original description pictures are figured, their labels are documented.

РЕЗЮМЕ. Обозначаются два неотипа Parnassius: Parnassius corybas Fischer de Waldheim, 1823 из «Камчатка, окр. пос. Эссо» и Parnassius nomion Fischer de Waldheim, 1823 из «Кяхта». Приводятся изображения неотипов и их этикеток, а также оригинальные иллюстрации Фишера де Вальдгейма.

The genus Parnassius Latreille, 1804 is a group of butterflies with endless interest among collectors: numerous specimens are preserved in institutional and private entomological collections. As a result of this interest we have a huge number of named species-group taxa (species, subspecies, local forms, morphs, aberrations etc.) which sometimes became a ground for some taxonomical battles [see, for example: Rose, 1995; Korb et al., 2016]. Basically, the only "progress" within the systematics of this genus is in the growing amount of described species-group taxa. The nomenclatural part of work within this group is still in some kind of ancient stage: not all species have properly designated name-bearing types, quite a lot of infrasubspecific taxa are still regarded as of subspecific rank without any evidence, etc. The situation is so neglected that even at the modern time some very common species can have unfixed nomenclatural issues. One of the most striking examples was solved only several years ago and still was not adopted by the majority of lepidopterists and by some "amateur parnassiologists". I mean the situa- tion with Parnassius phoebus (Fabricius, 1793), discussed by Hanus and Thèye [2010] and partially resolved by them by designating a neotype for this taxon [Hanus, Thèye, 2013]. The request of Balletto and Bonelli [2014] to suppress the name P. phoebus by using the plenary power of the International Commission on Zoological Nomenclature, was not approved [ICZN, 2017]. Article 75.3 of the Code requires that "A neotype is validly designated when there is an exceptional need and only when that need is stated expressly.". In the text below I will show, that the neotype of $P$. corybas Fischer de Waldheim, 1823 expressly needed to resolve the situation between $P$. phoebus, $P$. ariadne (Lederer, 1853) and $P$. corybas where is still a mess present after the neotype designation for $P$. phoebus, and the neotype designation of $P$. nomion Fischer de Waldheim, 1823 is expressly needed because its type locality occupy three subspecies of this species and the type locality to resolve this problem can be fixed by only primary type designation.

One of the results of Hanus and Thèye work was the replacement of two Parnassius names, supported by cited Opinion [ICZN, 2017]: the taxon previously known as $P$. ariadne is now $P$. phoebus, and the taxon which was for a long time listed as $P$. phoebus is now known under the oldest available name $P$. corybas. But the problem was not resolved completely by these two authors: they designated the neotype of $P$. phoebus, but no primary type of $P$. corybas was selected.

The collection of G. Fischer de Waldheim was lost in a fire in Moscow [Lyubarsky, 2009; Anikin et al., 2017], no type specimen from this collection survived. Parnassius corybas was introduced in the famous book "Entomographie de la Russie" [Fischer de Waldheim, 1823-1824] from "Kamtschatka". At the same time and in the same monograph the name Parnassius nomion was established with the type locality "Dau-

How to cite this article: Korb S.K. 2018. Two Parnassius neotype designations (Lepidoptera: Papilionidae) // Russian Entomol. J. Vol.27. No.2. P.203-206. doi: 10.15298/rusentj.27.2.11 
ria", but the term "Dauria" is quite wide and includes the lands of Buryatia, Transbaikal, Amur region, North Mongolia and closely located areas, so it is area of at least three subspecies of $P$. nomion at present (nominate, $P$. nomion dis Groum-Grshimaïlo, 1890 and $P$. nomion aurora Bang-Haas, 1933); its type is also lost. So, actually both $P$. corybas and $P$. nomion required the neotype designation: first one by the reason described above, and the second one by the reason of the clearance of its type locality to place the nominate subspecies in its correct region. Some of the "Entomographie de la Russie" volumes were prepared by Fischer de Waldheim together with Eversmann which also was in constant entomological exchange with him. So, it is logic to conclude, that Eversmann had seen at least part of Fischer de Waldheim's material and, possibly, had some specimens from Fischer de Waldheim in his collection. The collection of Eversmann is now deposited in the Zoological Institute of the Russian Academy of Sciences (St.-Petersburg, Russia), and some part of it is also in the collection of the Kazan University where it came from Eversmann's student, A.M. Butlerov; according to the data of Bremer [1867: 4], in this collection must be preserved five specimens of $P$. corybas and four of $P$. nomion. It is important to point out, that in the catalogue of E. Eversmann's collection, published by Bremer [op. cit.] both taxa are listed clearly with the authorship of F.[ischer] d.[e]
$\mathrm{W}$.[aldheim] and under the names the latter gave to them. Thus, for the neotype designations of both taxa the material from the collection of Eversmann is the best match.

Unfortunately, in the above mentioned collection only one original Eversmann specimen of $P$. corybas is present, but it is from another locality ("Dauria"). Thus it is unlogic to use this specimen for the neotype designation. I designate here as the neotype of Parnassius corybas Fischer de Waldheim, 1823 a male specimen from Kamchatka. This specimen has two labels: "26.06.1994 Russia|Kamchatka|Esso environs" (white paper, printed), “26.06.1994 Россия | Камчатка | окр. пос. Эссо" (white paper, printed) (Figs 1-5); it is preserved in the collection of the Zoological Institute of the Russian Academy of Sciences, St.-Petersburg, Russia. P. corybas was originally described by Fischer de Walheim based on a female specimen, whereas the proposed neotype is a male because over $95 \%$ of all primary types within Parnassius are males and thus it is better to have this one as the male too to have better base for comparison in future.

Thus, the type locality of $P$. corybas after the neotype designation is: Russia, Kamchatka, environs of the settlement Esso, coordinates: 55 $552503 \mathrm{~N}, 158^{\circ}$ 412413E.

The situation with $P$. nomion in the Eversmann collection is better. The only one specimen was found
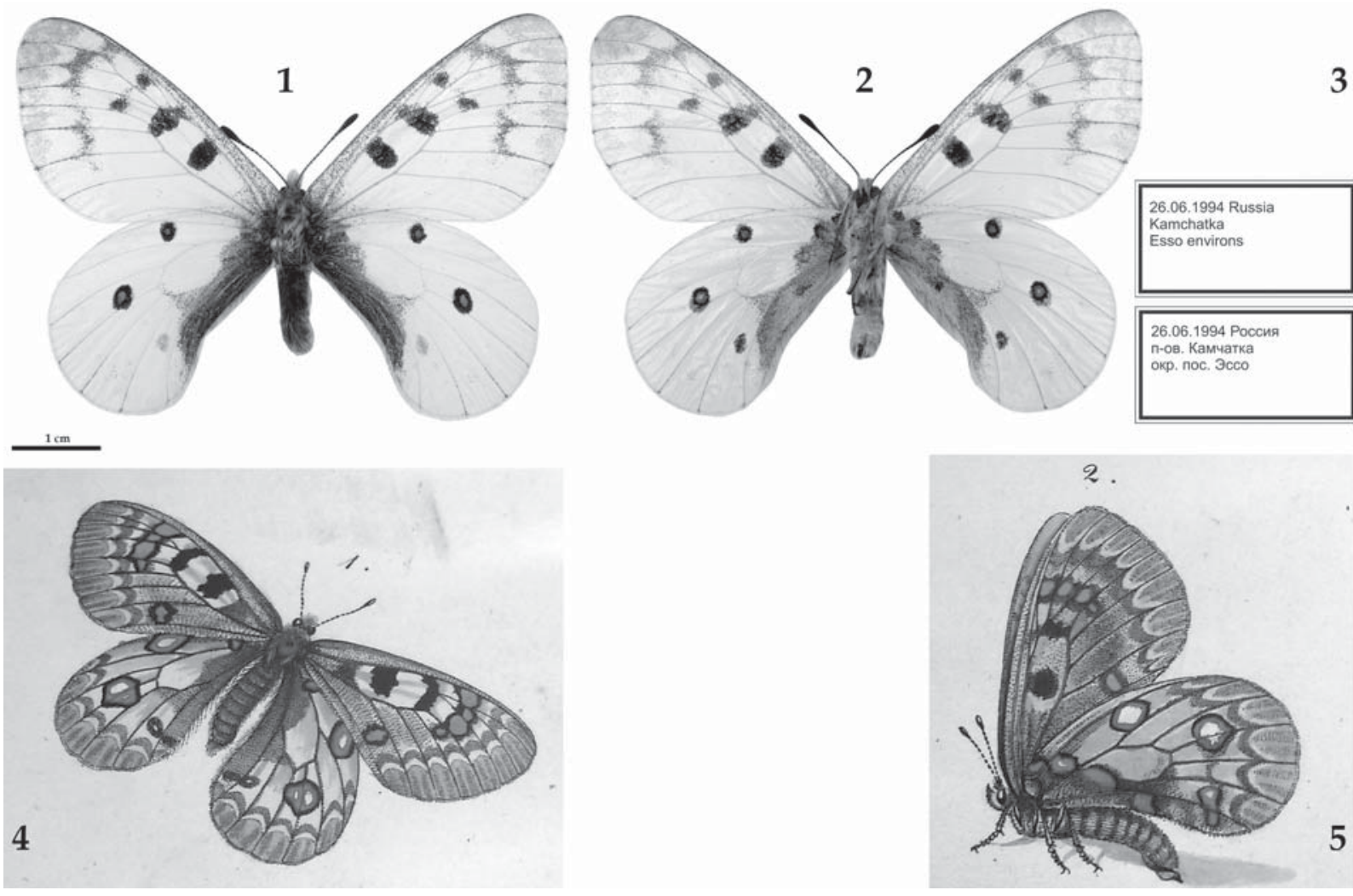

Figs 1-5. Parnassius corybas: 1-2 - neotype male; 3 - neotype labels; 4-5 - original figures from the "Entomographie de la Russie", pl. 6 (female specimen figured).

Рис. 1-5. Parnassius corybas: 1-2 — неотип, самец; 3 - этикетки неотипа; 4-5 — оригинальные иллюстрации из “Еntomographie de la Russie", pl. 6 (изображена самка). 
by my request in the Zoological Institute of the Russian Academy of Sciences, but it is the perfect match to the published by Fischer de Waldheim figures of this species [1823: pl. 6, figs. 3, 4]; see Figs 6-8, 10 of current paper. Two specimens with E. Eversmann labels ("Kiachta") are deposited in the Kazan University collection. I designate here the neotype of Parnassius nomion Fischer de Waldheim, 1823, the male specimen, preserved in the collection of the Zoological Institute of the Russian Academy of Sciences. This specimen has five labels: yellow rectangle with no inscripts or inprints, "Onon Anfang | July" (white paper, handwritten, unknown hand), "Parnassius | nomion" (white paper, handwritten, unknown hand), "coll. Acad. | Petrop." (white paper, printed), "Bremer 6." (white paper, handwritten, E. Eversmann's hand) (Figs 6-10).

Thus, the type locality of $P$. nomion after the neotype designation is: Russia, Transbaikal, environs of the Kyakhta city, coordinates: $50^{\circ} 212003$ N, $106^{\circ} 272003$ E.

ACKNOWLEDGMENTS. I am very thankful to Dr A.Y. Matov and Dr A.L. Lvovsky (St.-Petersburg, Russia) who searched the specimens of Parnassius in the Eversmann collection by my request and prepared their photographs to me. I am very grateful to Dr V.V. Zolotuhin (Ulyanovsk, Russia) who gave me information about the type specimens of Fischer de Waldheim and the idea, that the best chance to designate right neotypes is to use the Eversmann's collection; I am very thankful to him for granting access to some rare literature sources and his data about Eversmann's Parnassians stored in the collection of Kazan University.

\section{References}

Anikin V.V., Sachkov S.A., Zolotuhin V.V. 2017. "Fauna lepidopterologica Volgo-Uralensis": from P. Pallas to present days // Proceedings of the Museum Witt Munich. Vol.7. P.3-374.

Balletto E., Bonelli S. 2014. Case 3637. Papilio phoebus De Prunner, 1798: proposed conservation in its accustomed usage by suppression of Papilio phoebus Fabricius, 1793 (Insecta, Lepidoptera, Papilionidae) // Bulletin of Zoological Nomenclature. Vol.71. No.2. P.75-80.

Bremer O. 1867. Catalog der Lepidopteren-Sammlung des Professors Dr. Eversmann // Horae Societatis Entomologicae Rossicae. T.5. P.1-23 (this paper has its own pagination and is located at the end of the volume, before the plates).

Fischer de Waldheim. G. 1823-1824. Entomographie de la Russie. T. 2. Moscow: Typis Augusti Semen. [2] $+x x+264$ pp., 40 pls. [plates published in 1823, the text after November 1824].

Hanus J., Thèye M.-L. 2010. Parnassius phoebus (Fabricius, 1793), a misidentified species (Lepidoptera: Papilionidae) // Nachrichten des entomologischen Vereins Apollo. N.F. Bd.31. Hf.1/2. S.71-84.

Hanus J., Thèye M.-L. 2013. Les premiers Parnassius: histoire de leur découverte, de leur description et de l'erreur d'identification
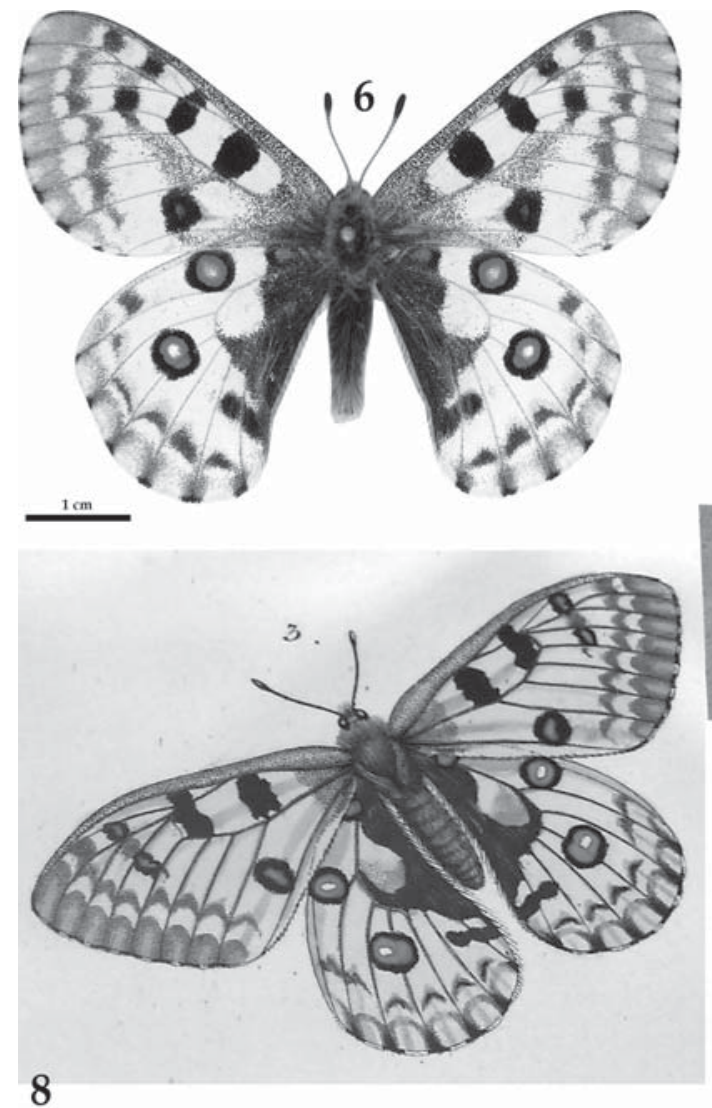

9

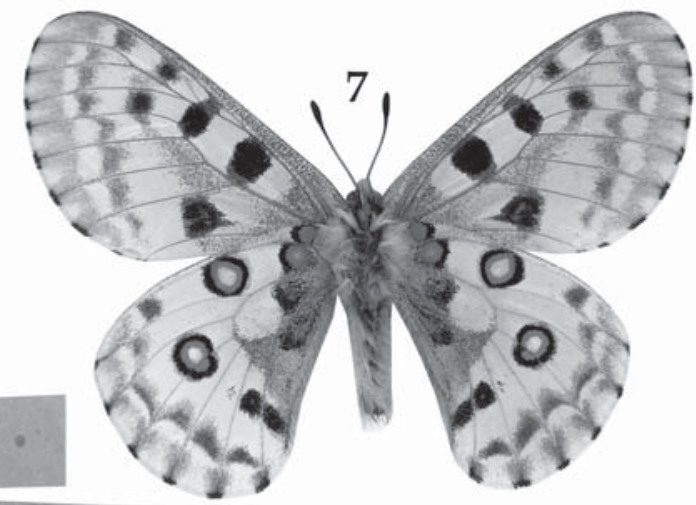

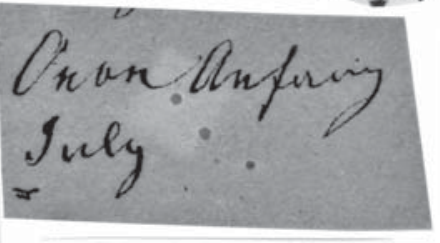

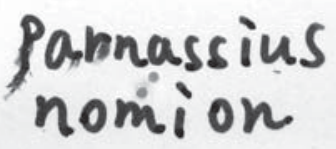

coll. Acad. Petrop.

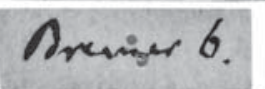

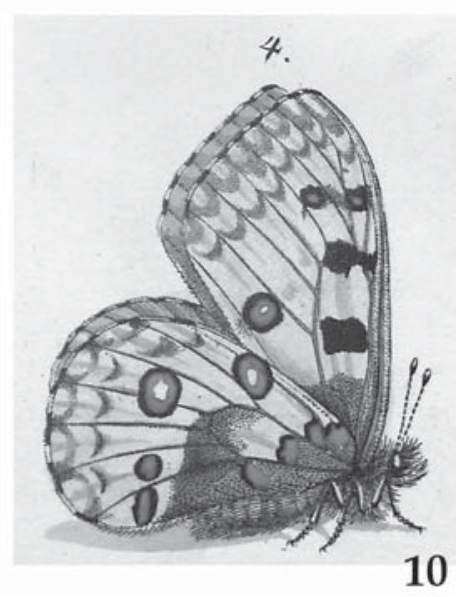

Figs 6-10. Parnassius nomion: 6-7 - neotype male; 8-10 - original figures from the "Entomographie de la Russie", pl. 6 (male specimen figured); 9 - neotype labels.

Рис. 6-10. Parnassius nomion: 6-7 - неотип, самец; 8-10 - оригинальные иллюстрации из "Entomographie de la Russie", pl. 6 (изображён самец); 9 - этикетки неотипа. 
de Parnassius phoebus (Fabricius, 1793) (Lepidoptera Papilionidae) // Alexanor. T.25. No.6. P.323-354.

ICZN. 2017. Opinion 2382 (Case 3637) - Conservation of the accustomed usage of Papilio phoebus De Prunner, 1798 by suppression of Papilio phoebus Fabricius, 1793 not approved (Insecta, Lepidoptera, Papilionidae) // Bulletin of Zoological Nomenclature. Vol.73. No.2-4. P.148-149.

Korb S.K., Fric Z.F., Bartonova A. 2016. Phylogeny of Koramius charltonius (Gray, 1853) (Lepidoptera: Papilionidae): a case of too many poorly circumscribed subspecies // Nota lepidopterological. Vol.39. No.2. P.169-191.

Lyubarsky G.Y. 2009. [The history of the Zoological Museum of the Moscow University: ideas, persons, structures.] Moscow: KMK Scientific Press. 743 p. [In Russian]

Rose K. 1995. Zur Unterarten-Inflation in der Gattung Parnassius (Lepidoptera: Papilionidae) // Nachrichten des entomologischen Vereins Apollo. N.F. Bd.16. No.2/3. S.243-252. 